\title{
Oliver Miles 6 March 1936-10 November 2019
}

\author{
By Hugh Miles
}

Oliver Miles, a distinguished British diplomat and noted Arabist, died on 10 November 2019 of pancreatic cancer. He was 83. Richard Oliver Miles was born on 6 March 1936 and educated at Ampleforth and at Merton College, Oxford, where he read classical mods followed by oriental languages and got a first class degree in both. At the age of 24 he entered the Diplomatic Service and he served in Abu Dhabi, Amman, Mukalla, Aden and Jedda. He played a key role in ending Britain's colonial role in what is now Yemen, and had a lifelong love of the people of the Arabian Gulf, becoming one of the Diplomatic Service's leading experts on Arab and Middle East affairs. He also had mid-career postings to Cyprus, during General Grivas' struggle to annex Cyprus to Greece, and to Athens, where he would return as ambassador at the end of his career. In 1980 he became head of NENAD, the Near East and North Africa Department and in 1984 he was appointed ambassador to Libya, a posting which lasted only four months before diplomatic relations were broken off following the murder of WPC Yvonne Fletcher.

Miles had been to Libya during his tenure at NENAD so had some prior understanding about the country, but as ambassador he found Libya an unpredictable, exciting place which seemed to offer both lots of snakes and lots of ladders. When he arrived in January 1984 the ladders seemed to be in the ascendant, the British government having got over some of the extreme difficulties they had faced in their relations with Gaddafi in previous years and hopes were mounting that perhaps some constructive work together might be possible. But just as relations were starting to improve the disastrous news from London broke that a police woman had been shot outside the Libyan People's Bureau in St. James's Square. Within a couple of days he received instructions to break off diplomatic relations, which he did. The Libyan diplomats in the People's Bureau in London were given a week to leave the UK and so of course Gaddafi gave the British a week to get out of Tripoli. A terrific scramble ensued and though it was a very tense and difficult situation - the Libyans had burned buildings down in the past including the Jordanian embassy

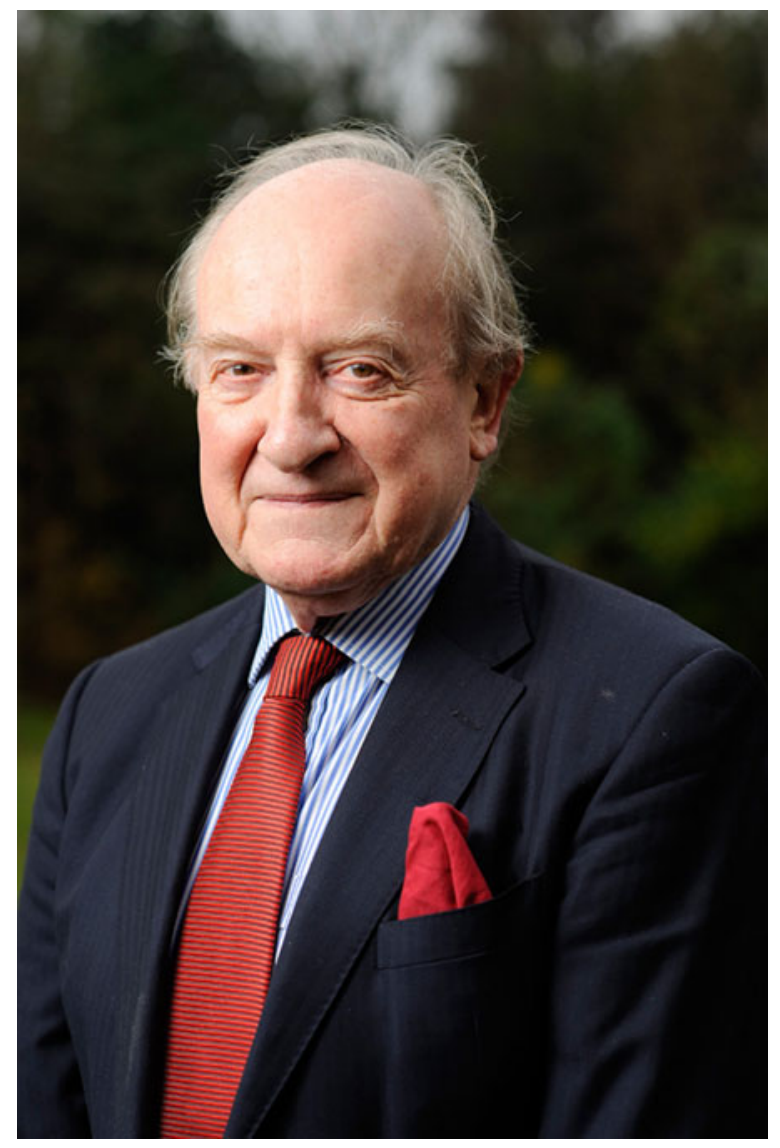

Figure 1. Oliver Miles (Photo: Mr. Nasir Hamid).

although they did supply the ambassador with a ladder to escape - all the British detained in Libya emerged unscathed.

$\mathrm{He}$ went on to be British ambassador to Luxembourg and Greece, interspersed with roles at the United Nations in New York, in Northern Ireland and as first head of Britain's trade promotion body, a joint directorate of the Foreign Office and Department of Trade. He also organised a NATO summit and the London Conference on Yugoslavia.

He was a fluent Russian speaker, having done his national service as a Royal Navy interpreter, and had a lifelong love of Russia and Russian literature. While at Oxford he joined a university trip to Moscow, and while there he and the Oxford professor used the pretext of religious observance to excuse themselves from the prepared programme, slipping off together to visit the dissident author Boris Pasternak, with 
whom they spent a memorable day. However, he was never posted to Russia, having twice met the Soviet spy George Blake - Blake tried to recruit him at Oxford and then turned up with a different name at MECAS, the Arabic language school in Lebanon.

After a career dedicated to loyal diplomatic service, Miles became a vocal and principled critic of foreign policy and diplomatic practice. He made a big splash in 2004 as the organiser of an open letter to Tony Blair, signed by 52 former Ambassadors, criticising what they saw as slavish adherence to American policy in Iraq and Palestine.

The Libyan diplomatic upheaval of 1984 had thrust the family briefly into the media spotlight, turning his wife Julia into an overnight star, and his new media profile - unlikely for such an unshowy and reserved public servant - turned into a mainstay of his retirement. He was uniquely capable of commenting with authority on Libyan affairs - a valuable resource for journalists trying to grapple with Gaddafi, recurrent questions about the Lockerbie air disaster, and then the Arab Spring in 2011. Miles became a regular media commentator as Libya repeatedly returned to the headlines, and his expertise was in demand for insights into the Arab world and diplomacy in general. He was a frequent voice on television and radio and away from the headlines he founded a leading newsletter on Middle Eastern affairs, now known as Arab Digest, and he also worked as a consultant on government leak enquiries, chaired a charity that helped house foreign students in Britain, and occasionally - and with great enthusiasm - worked as an election observer in the backwaters of the former Soviet Union.

$\mathrm{He}$ is survived by his wife Julia and their four children, Joe, Tom, Hugh and Lucy. 